〔J. Appl. Glycosci., Vol.46, No.1, p. 1-7 (1999)〕

\title{
Oxidation of Uronic Acids by a Large Excess of Glucose Oxidase Preparations
}

\author{
Mikihiko Kobayashi,* Hirofumi Nishihara' ${ }^{1}$ and Shoichi Kobayashi \\ National Food Research Institute (2-1-2, Kannondai, Tsukuba 305-8642, Japan) \\ ${ }^{1}$ Department of Applied Bioresource Science, School of Agriculture, Ibaraki University \\ (3998 Ami-machi, Ibaraki 300-0393, Japan)
}

\begin{abstract}
Three commercial enzyme preparations of glucose oxidase (GOD) showed an oxidizing ability of glucuronic acid and galacturonic acid to form sugar acids. The optimum conditions of GOD reaction were at $\mathrm{pH} 8.0$ and $50^{\circ} \mathrm{C}$, whereas those of uronic acid oxidase (UOD) reaction were at $\mathrm{pH} 3.5$ and $40^{\circ} \mathrm{C}$. In spite of extensive attempts to separate GOD from UOD, the isolation of each activity was unsuccessful, and UOD reaction resulted from the wide substrate specificity of GOD reaction. More than 6 -fold higher $K_{\mathrm{m}}$ values for glucuronic acid and galacturonic acid than for glucose might suggest that UOD reaction was the alternative reaction of GOD enzyme. However, a more definite conclusion on UOD activity should be drawn from further studies. The reaction products from uronic acids were analyzed by HPLC and paper chromatography, and some products were shown to be identical with sugar acids.
\end{abstract}

Beet pulp contained a large amount of uronic acids, which were found not only in the pectic fraction, but also in the hemicellulose and cellulose fractions. ${ }^{1)}$ Although the effective saccharification of beet pulp might increase biomass content about 1.4-fold for the ethanol production by yeast fermentation, uronic acids could not be used as carbon sources. The chemical conversion of uronic acids by watersoluble carbodiimide increased the yield of glucose and galactose in beet pulp fraction on enzymic hydrolysis with pectinases and hemicellulases. ${ }^{2}$ However, no papers were found concerning the enzymic reduction of uronic acids to neutral sugars. We have been screened the enzyme that converted uronic acids to neutral sugar. In contrast to our object, no enzyme concerning the production of neutral sugar from acidic sugar was obtained, but reaction catalyzing a further oxidation of uronic acids was observed. In the present paper, we describe the

*To whom correspondence should be addressed. Present address: Akita Research Institute for Food and Brewing (4-26, Sanuki, Araya-machi, Akita 010-1623, Japan) oxidation of uronic acids with glucose oxidase (GOD) preparation from commercial sources.

\section{MATERIALS AND METHODS}

Materials. Three preparations of glucose oxidase were obtained from Toyobo (GOD ${ }^{\mathrm{T}}$ : 165 units $/ \mathrm{mg}$, isolated from Aspergillus species), Wako Pure Chemical Industries Ltd. (150-250 units/mg, isolated from Aspergillus niger), and Oriental Yeast Co. (348 units/mg, isolated from microorganism). The glucose was measured by the glucose oxidase kit (Glucose B-Test Wako). Horseradish peroxidase (100 units/ mg) was purchased from Wako Pure Chemical Industries Ltd. Most sugars, including sugar acids, were commercial preparations purchased from Wako.

Assay of uronic acid oxidizing activity. The reaction mixture contained enzyme solution $(20 \mu \mathrm{L})$, substrate solution $(10 \mu \mathrm{L})$, and buffer solution including additional components (20 $\mu \mathrm{L})$. After incubation at $30^{\circ} \mathrm{C}$ for $20 \mathrm{~min}$, the reaction was stopped by the addition of $1 \mathrm{M}$ $\mathrm{NaOH}(25 \mu \mathrm{L})$. The mixture was neutralized 
with $1 \mathrm{M} \mathrm{HCl}(25 \mu \mathrm{L})$ and subjected to a UOD assay, which was essentially based on the GOD assay kit of B-Test Wako. For the UOD assay, a cocktail from the GOD assay kit was treated at $100^{\circ} \mathrm{C}$ for $5 \mathrm{~min}$ for the inactivation of GOD; that is, phenol and 4-aminophenazone in the GOD cocktail were used. The peroxidase of horseradish $(0.2 \mathrm{mg} / \mathrm{mL} 67 \mathrm{~mm}$ phosphate buffer, $\mathrm{pH}$ 7.6) was supplemented for the UOD assay. Inactivated GOD cocktail $(100 \mu \mathrm{L})$ and peroxidase solution $(25 \mu \mathrm{L})$ were added to the above reaction mixture and incubated at $30^{\circ} \mathrm{C}$ for $20 \mathrm{~min}$. After dilution with water $(375 \mu \mathrm{L})$, absorbance was measured at $505 \mathrm{~nm}$. One unit each of GOD and UOD activity was defined as the amount of enzyme, which converted $1 \mu \mathrm{mol}$ glucose/min at $\mathrm{pH} 7.5$ (50 mM TEMED-HCl buffer) and $1 \mathrm{nmol}$ glucuronic acid/min at $\mathrm{pH}$ 3.5 (50 mM Tris-acetate buffer), respectively, at $30^{\circ} \mathrm{C}$ incubations. Calibration curves with standard sugars were obtained by the above methods, including alkaline inactivation and subsequent neutralization steps that required 2 or 3 min.

HPLC analysis. HPLC gel filtration analysis was done with Tosoh G3000SW column $(7.8 \times$ $300 \mathrm{~mm}$ ), which was equilibrated with $17 \mathrm{~mm}$ phosphate buffer ( $\mathrm{pH} 7.6$ ) $-0.2 \mathrm{M} . \mathrm{NaCl}-0.02 \%$ $\mathrm{NaN}_{3}$. GOT ${ }^{\mathrm{T}}$ was eluted from the column at $0.6 \mathrm{~mL} / \mathrm{min}$, and fractions. were collected every $30 \mathrm{~s}$ to measure the enzyme activity and protein by a UV detector (Jasco UV-870). The product sugars of UOD reaction were separated by the column of Aminex carbohydrate HPX-87C (7.8 $\times 300 \mathrm{~mm})$. The reaction mixture was eluted from the column with water $(0.6 \mathrm{~mL} / \mathrm{min})$, and sugars were detected by an RI detector (Jasco RI-830).

Paper chromatography (PPC). A product analysis of the UOD reaction was done with filter paper $(20 \times 20 \mathrm{~cm}$, Advantec Toyo, No. $50)$. The development was done at room temperature overnight with $65 \%$ 1-propanol, and sugars were detected by the silver nitrate dip procedure.

\section{RESULTS}

\section{Screening of UOD activity.}

About 40 commercial enzyme preparations, including some oxidases, were tested for the oxidase activity of glucuronic acid and galacturonic acid conversion. UOD activity was assayed for the production of $\mathrm{H}_{2} \mathrm{O}_{2}$ with the color development reaction coupled with peroxidase, phenol, and 4-aminophenazone. As shown in Table 1, three GOD preparations gave UOD activity. No remarkable UOD activity was detected from the remaining 37 enzyme preparations. Since GOD of Toyobo $\left(\mathrm{GOD}^{\mathrm{T}}\right)$ had the highest activity for galacturonic acid and was available in a large quantity at a low price, further experiments were done with this enzyme.

\section{Characteristic of UOD reaction.}

The general properties of the $\mathrm{GOD}^{\mathrm{T}}$ preparation in the reaction with galacturonic acid (UOD activity) were compared with those in the reaction with glucose (GOD activity). As shown in Fig. 1a, pH optimum for GOD activity was at $\mathrm{pH} 8.0$, and higher activity was obtained at neutral to alkaline $\mathrm{pH}$ ranges. In contrast, the maximum activity of UOD reaction was obtained at $\mathrm{pH} 3.5$; higher activity occurred at the acidic $\mathrm{pH}$ regions. A comparison of optimum temperatures also revealed a marked difference between the GOD and UOD activities. The former activity was maximum, at 40 to $60^{\circ} \mathrm{C}$, and the UOD reaction was maximum at 30 to $50^{\circ} \mathrm{C}$; about $60 \%$ of the UOD activities were detected at the low temperature of $10^{\circ} \mathrm{C}$, at

Table 1. The comparison of uronate oxidizing activity among the GOD preparations. ${ }^{a}$ '

\begin{tabular}{lrc}
\hline \multicolumn{1}{c}{ Enzymes } & GlcUA & GalUA \\
\hline GOD/Toyobo & 38 & 230 \\
GOD/Wako & 27 & 13 \\
GOD/Oriental & 637 & 112 \\
\hline
\end{tabular}

${ }^{a}$ The reaction mixture $(300 \mu \mathrm{L})$ contained enzyme (10 mg/mL, $100 \mu \mathrm{L}), 10 \%$ substrate sugar $(100 \mu \mathrm{L})$, and $0.2 \mathrm{M}$ TEMED-HCl buffer (pH 7.5, $100 \mu \mathrm{L})$. After incubation at $30^{\circ} \mathrm{C}$ for $20 \mathrm{~h}$, the enzyme activity was measured as described in the text. 

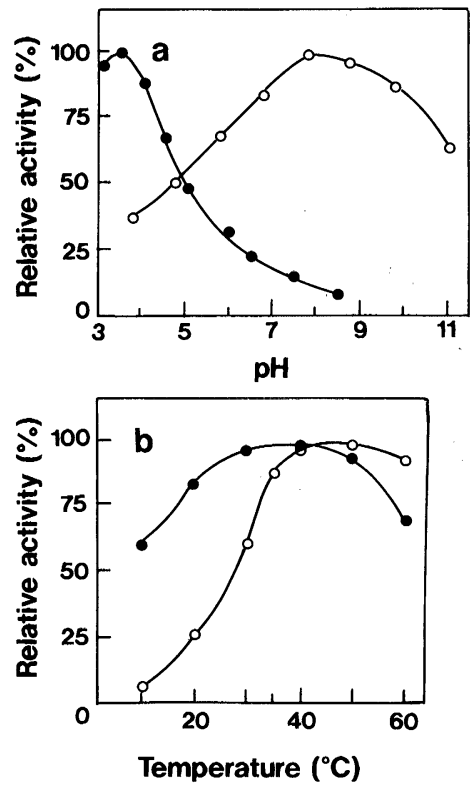

Fig. 1. Optimum conditions of GOD and UOD reactions.

(a) Optimum pH. (b) Optimum temperature. The reaction mixture $(100 \mu \mathrm{L})$ for GOD activity (O) contained GOD $^{\mathrm{T}}(10 \mu \mathrm{g} / \mathrm{mL}, 25 \mu \mathrm{L}), \quad 0.1 \mathrm{M}$ glucose $(25$ $\mu \mathrm{L}$ ), and $0.2 \mathrm{M}$ TEMED-HCl buffer ( $\mathrm{pH} 3.75-11.0,50$ $\mu \mathrm{L})$. After incubation at $30^{\circ} \mathrm{C}$ for $10 \mathrm{~min}$, the enzyme activity was measured as described in the text. The optimum temperature was measured at $\mathrm{pH} 8.0$. The reaction mixture $(100 \mu \mathrm{L})$ for UOD activity (O) contained $\mathrm{GOD}^{\mathrm{T}}(10 \mathrm{mg} / \mathrm{ml}, 25 \mu \mathrm{L}), 10 \%$ galacturonic

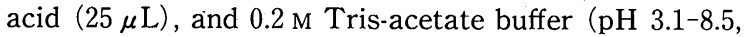
$50 \mu \mathrm{L}$ ). After incubation at $30^{\circ} \mathrm{C}$ for $20 \mathrm{~min}$, the enzyme activity was measured as above. The optimum temperature was measured at $\mathrm{pH} 3.5$.

which GOD activity was less than $10 \%$ (Fig. 1b).

The carbohydrate oxidizing activity of commercial GOD ${ }^{\mathrm{T}}$ preparation was examined with neutral and acidic sugars (Table 2). Although glucose and xylose gave significantly high activity, galactose and mannose also served as good substrates. Galacturonic acid and glucuronic acid were classified into the group of good substrates together with arabinose and glucosamine. Besides these sugars, glucurono $\gamma$ lactone, maltose, and sucrose were good substrates.

A comparison of kinetic constants for UOD and GOD reactions showed further differences
Table 2. The carbohydrate oxidizing activity of commercial $\mathrm{GOD}^{\mathrm{T}}$ preparation.

\begin{tabular}{lr}
\hline \multicolumn{1}{c}{ Substrate } & Activity (U) \\
\hline Arabinose & 619 \\
Galactose & 1168 \\
Glucose & 1413 \\
Mannose & 1095 \\
Xylose & 1572 \\
Galacturonate & 743 \\
Glucuronate & 430 \\
Glucosamine & 507 \\
Lactose & 92 \\
Maltose & 665 \\
Sucrose & 464 \\
Gluconate & 9 \\
Glucono $\delta$-lactone & 13 \\
Glucurono $\gamma$-lactone & 252 \\
Gulono $\gamma$-lactone & 8 \\
None & 6 \\
\hline
\end{tabular}

${ }^{a}$ The reaction mixture $(80 \mu \mathrm{L})$ contained enzyme $(10 \mathrm{mg} / \mathrm{mL}, 10 \mu \mathrm{L}), 1 \%$ substrate sugar $(20 \mu \mathrm{L})$,

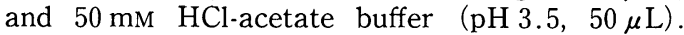
After incubation at $30^{\circ} \mathrm{C}$ for $20 \mathrm{~h}$, the enzyme activity was measured as described in the text.

as shown in Figs. $2 \mathrm{a}$ and $\mathrm{b}$. The GOD ${ }^{\mathrm{T}}$ preparation gave biphasic lines for glucuronic acid and galacturonic acid; two extrapolated $K_{\mathrm{m}}$ values, 99 and $329 \mathrm{~mm}$ for glucuronic acid; and 86 and $235 \mathrm{~mm}$ for galacturonic acid. In contrast, the $K_{\mathrm{m}}$ value for glucose was $13.2 \mathrm{mM}$ at $\mathrm{pH} 7.5$, whereas the $K_{\mathrm{m}}$ value was $25.5 \mathrm{~mm}$ at $\mathrm{pH} 3.5$. A comparison of the $k_{0}$ values showed a large difference in the UOD and GOD reactions. The $k_{0}$ values for galacturonic acid (1.2-2.7 $\left.\mathrm{min}^{-1}\right)$ were about 1000 -fold smaller than those for glucose $\left(1.2\right.$ and $2.9 \times 10^{3} \mathrm{~min}^{-1}$ at $\mathrm{pH} 7.5$ and $\mathrm{pH}$ 3.5 , respectively).

\section{Separation of UOD from GOD activity.}

To determine whether UOD activity was identical with GOD activity, a separation of UOD and GOD activities was examined by various column chromatography methods, including a con A-Sepharose column for the separation of glycoproteins. Most results gave no clear separation of the two activities. That is, as shown in Fig. 3 the activities and the protein peak had identical behaviors on the gel filtration chromatography. Moreover, on the PAGE separation, the major peak of UOD activity 


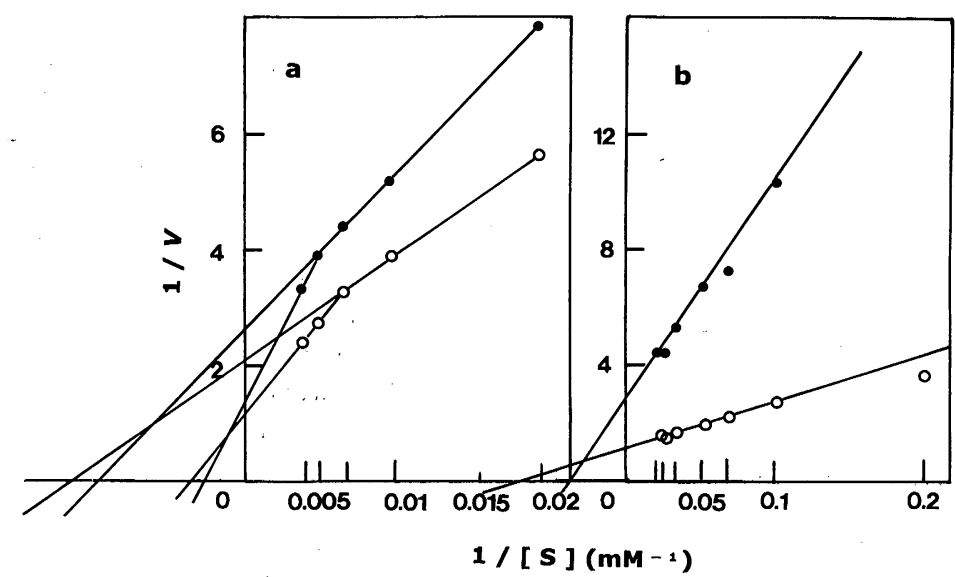

Fig. 2. Double reciprocal plots for UOD and GOD reactions.

(a) UOD reaction with glucuronic acid (O) and galacturonic acid (O). The reaction mixture $(50 \mu \mathrm{L})$ contained $\mathrm{GOD}^{\mathrm{T}}(10 \mathrm{mg} / \mathrm{mL}, 25 \mu \mathrm{L})$ and

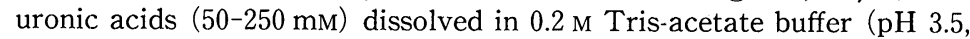
$25 \mu \mathrm{L}$ ). Incubation was done at $30^{\circ} \mathrm{C}$ for $20 \mathrm{~min}$. (b) GOD reaction with glucose at $\mathrm{pH} 3.5(-)$ and $\mathrm{pH} 7.5(\mathrm{O})$. The reaction mixture $(50 \mu \mathrm{L})$ contained $\mathrm{GOD}^{\mathrm{T}}(10 \mu \mathrm{g} / \mathrm{mL}, 25 \mu \mathrm{L})$ and glucose $(5-50 \mathrm{~mm})$ dissolved in $0.2 \mathrm{M}$ TEMED-HCl buffer $(\mathrm{pH} 3.5$ or $7.5,25 \mu \mathrm{L}$ ). Incubation was done at $30^{\circ} \mathrm{C}$ for $10 \mathrm{~min}$. $V$ values in $y$ axis were represented by the GOD unit of glucose $\mu \mathrm{mol}$ and thus multiplied to $1000 / 6$ times for the UOD reaction in (a). Therefore $K_{\mathrm{m}}$ and $V_{\max }$ values were calculated as follows: (a) UOD with glucuronic acid, 99 and $0.044 ; 329$ and 0.080 , and with galacturonic acid, 86 and $0.037 ; 235 \mathrm{~mm}$ and $0.064 \mathrm{nmol}$ as glucuronic $\mathrm{acid} / \mathrm{min} / \mathrm{mg}$ enzyme, respectively; (b) GOD with glucose at $\mathrm{pH} 3.5,25.5$ and 34.5 , and at $\mathrm{pH} 7.5,13.2 \mathrm{~mm}$ and $83.3 \mu \mathrm{mol}$ glucose $/ \mathrm{min} / \mathrm{mg}$ enzyme, respectively.

corresponded to that of GOD activity (relative mobility; $R_{\mathrm{m}} 0.53$ ) and gave no indication of a separation of UOD and GOD, which was measured with the sliced gel segments from PAGE and SDS-PAGE (data not shown). From all these results we might conclude that UOD and GOD reactions were catalyzed by the identical enzyme molecule of GOD. However, a more definite conclusion for the identity of UOD and GOD enzymes should be drawn from further studies.

\section{Analysis of the products.}

Based on the reaction mechanism of GOD activity, the reaction products from uronic acids and UOD reaction were assumed to be the oxidized form of the aldehyde group at the C-1 position. Namely, galactaric acid and glucaric acid were produced from galacturonic acid and glucuronic acid, respectively. Therefore a comparison of $R_{\mathrm{T}}$ (relative retention time) and $R_{\mathrm{Glc}}$ (relative mobility to glucose) values of reaction products with the standard sugars was made by HPLC and paper chromatography (PPC), as shown in Table 3. HPLC analysis revealed two main product peaks of $R_{\mathrm{T}} 8.5$ and $9.8 \mathrm{~min}$, besides the substrate glucuronic acid. A major product of $R_{\mathrm{T}} 7.3 \mathrm{~min}$ was obtained from the substrate galacturonic acid. Sample peaks at 8.5 and 7.3 min were almost identical to peaks 8.4 and $7.2 \mathrm{~min}$ of standard glucaric acid and galactaric acid, respectively. Three lactones had $R_{\mathrm{T}}$ values of more than $10 \mathrm{~min}$ and higher $R_{\mathrm{G} 1 \mathrm{c}}$ values (1.08-1.29) than glucose $\left(R_{\mathrm{Glc}} 1.00\right)$ on the PPC analysis. The reaction products from glucuronic acid had $R_{\mathrm{Glc}} 0.81$ and 0.60 , and product from galacturonic acid had $R_{\text {Glc }} 0.88$ (Table 3). Standard glucaric acid and galactaric acid gave three spots $\left(R_{\mathrm{Glc}} 0.80,0.63\right.$, and 0.49$)$ and two spots $\left(R_{\mathrm{Glc}} 0.78\right.$ and 0.63$)$, 


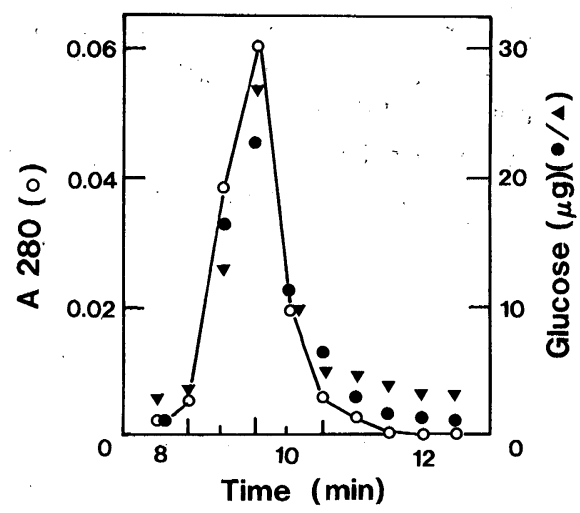

Fig. 3. HPLC gel filtration pattern of $\mathrm{GOD}^{\mathrm{T}}$ preparation.

The enzyme solution $(10 \mathrm{mg} / \mathrm{mL}, 20 \mu \mathrm{L})$ was subjected to the analysis as described in the text. Protein $(\bigcirc)$, GOD activity ( ), and UOD activity. ( $\boldsymbol{\nabla}$ ) were measured for the isolated fractions $(300 \mu \mathrm{L} /$ tube $)$. GOD activity was represented by glucose $(\mu \mathrm{g})$ equivalent value, and UOD activity was represented by the same value multiplied 1000 -fold after the conversion of the UOD unit into the GOD unit, where the GOD 1.0 unit corresponded with the UOD 0.006 unit.

Table 3. The comparison of $R_{\mathrm{T}}$ and $R_{\mathrm{Glc}}$ values of reaction products with standard sugars.

\begin{tabular}{lcl}
\hline Sugars & $\operatorname{HPLC}\left(R_{\mathrm{T}}, \min \right)^{a}$ & $\operatorname{PPC}\left(R_{\mathrm{GlC}}\right)^{a}$ \\
\hline Markers & & \\
Glucose & 9.8 & 1.00 \\
Galacturonate & 8.1 & 0.75 \\
Glucuronate & 7.5 & 0.72 \\
Glucono $\delta$-lactone & 11.4 & 1.29 \\
Glucurono $\gamma$-lactone & 12.7 & 1.13 \\
Gulono $\gamma$-lactone & 12.0 & 1.08 \\
Galactonate & - & 0.66 \\
Gluconate & 11.2 & 0.67 \\
Galactarate & 7.2 & $0.78,0.63$ \\
Glucarate & $8.4,7.4$ & $0.80,0.63,0.49$ \\
Products from & & \\
Galacturonate & $(8.1), 7.3$ & $0.88,(0.74)$ \\
Glucuronate & $9.8,8.5,(7: 7)$ & $0.81,(0.72), 0.60$ \\
\hline
\end{tabular}

${ }^{a}$ Values in parentheses corresponded to the peaks or spots detected in the reaction mixture at zero time.

respectively. Because large amounts of residual substrates in the reaction mixture greatly affected the $R_{\mathrm{T}}$ and $R_{\mathrm{Glc}}$ values of product sugars, some deviations of values from the authentic sugars were observed. Moreover, it was already known that sugar acid had several isomers, such as 1,4-lactone, 3,6-lactone, and di-lactone forms. Therefore the spots of reaction products could not be firmly identified as authentic sugar acids in both cases of glucuronic acid and galacturonic acid.

\section{DISCUSSION}

During the screening of enzyme, which catalyzes the reduction of uronic acids to neutral sugars, commercial preparations of glucose oxidase were found to catalyze the oxidation of uronic acids (Table 1). In these experiments, high concentrations of enzyme (final $0.25 \%$ ) and substrate uronic acids (final 2.5\%) were adopted. It has already been noticed that GOD catalyzed the oxidation of several neutral sugars besides glucose. ${ }^{3,4)}$ However, usually, no examination of the substrate specificity with acidic sugars was reported. Under the above conditions of a particular high enzymesubstrate system, UOD reaction could be detected with the colorimetric determination method, though reaction with an ordinary level of GOD concentration gave no noticeable amount of reaction product. The GOD preparation had high activity to glucuronic acid, galacturonic acid, and glucosamine besides neutral monosaccharides other than glucose (Table 2). Therefore we focused on this uronic acid oxidizing activity and examined the characteristics of UOD in detail. Although glucurono $\gamma$-lactone was susceptible to UOD, other lactones tested had no reaction with it. Moreover, some disaccharides such as lactose, maltose, and sucrose were oxidized with this enzyme. In the earlier paper, an oxidation of lactose, maltose, and cellobiose by GOD was observed.5) Different from the above three disaccharides, sucrose has no reducing end group, and the action of UOD is limited to positions other than C-1. Thus the first possibility of high value with sucrose shown in Table 2 may be attributable to the acidic hydrolysis of sucrose at $\mathrm{pH} 3.5$ and the subsequent oxidation of resulting glucose with GOD. An enzymic cleavage of sucrose molecule indicates a second possibility, where the oxidation of sucrose might be ascribed to the cooperation with some other contaminated enzymes such as invertase with GOD yielding the oxidation of glucose and fructose. In 
this consequence, biphasic kinetics shown in Fig. $2 \mathrm{a}$ could be explained by, the action of a contaminated enzyme. Alternatively, other factors such as a change of $\mathrm{pH}$ or an increase of product inhibition, which might occur because the high concentration of acidic sugar substrates and the reaction mechanism yielding $\mathrm{H}_{2} \mathrm{O}_{2}$ would lead to biphasic lines. Biphasic lines were also reported on the kinetic experiments done with purified enzymes of dextransucrase. ${ }^{6,7)}$ The third possibility may be attributable to contaminated enzymes such as the other type of oxidase having specificity to positions other than $\mathrm{C}-1$, which catalyzed the direct oxidation of sucrose molecules. Moreover, it was interesting to note that the oxidation of galactose was catalyzed by two types of galactose oxidases, the predominant type oxidized at the $\mathrm{C}-6$ position ${ }^{8)}$ and the minor type oxidized at the C-1 position of galactose.9)

Since the optimum conditions of GOD and UOD reactions differed greatly (Fig. 1a, b), the separation of UOD from GOD was extensively tested. However, no separation of the two activities was attained, as illustrated by Fig. 3, and we concluded that the UOD activity was ascribed to the wide substrate specificity of GOD reaction. A large increase in the enzyme and substrate concentrations made it possible to detect current UOD activity. A difference in optimum $\mathrm{pH}$ and temperature shown in Fig. 1 might be related to the formation of the dissociated free-acid form of acidic sugars other than the salt form, although further evidence should be required to verify this idea. Based on the results in Fig. 1, at first we considered that the UOD enzyme was different from GOD and made extensive trials to separate the two, but no experiments provided evidence for differentiation of the two enzymes. Therefore we should suggest the identity of UOD activity with GOD activity. However, the identity of these activities should be confirmed by further studies on enzyme characteristics. Although some recent studies reported the enzymic oxidation of neutral sugars, ${ }^{10,11)}$ the oxidation of acidic sugars would be another useful method for the production of carboxylated sugars. In most cases, sugar acids such as glucaric acid and galactaric acid were currently produced by the chemical reactions catalyzed by monochloroacetic acid. ${ }^{12,13)}$

The action of UOD on glucuronic acid and galacturonic acid produced one or two sugars, ${ }^{14,15)}$ which were analyzed by HPLC and PPC methods (Table 3). Although no definite assignment of products was completed, the substrates were oxidized at the $\mathrm{C}-1$ position of the aldehyde group, and the product had a dicarboxylated form. One piece of additional evidence was provided by the measurement of reducing power by the Nelson-Somogyi method during the reaction of UOD with galacturonic acid (data not shown). As presented in Fig. 1a, UOD activity was higher at acidic $\mathrm{pH}$ than at alkaline $\mathrm{pH}$, and the decrease in reducing power of galacturonic acid was also higher at acidic $\mathrm{pH}$. A loss of reducing power during the UOD reaction would be explained by the oxidation of the aldehyde group to form the carboxyl group at $\mathrm{C}-1$ position. More definite evidence will be provided for the isolated products by further analysis with such as mass spectrometry.

This work was supported by the Department of Ministry of Agriculture, Forestry, and Fisheries of Japan through the National Project of Bio-Renaissance.

\section{REFERENCES}

1) M. Kobayashi, K. Funane, H. Ueyama, S. Ohya, M. Tanaka and Y. Kato: Biosci. Biotech. Biochem., 57, 998-1000 (1993).

2) M. Kobayashi, K. Funane, H. Ueyama, S. Ohya and Y. Kato: Biosci. Biotech. Biochem., 58, 1973-1976 (1994).

3) R. Bentley : Methods Enzymol., 1, 340-345 (1955).

4) B. E. P. Swoboda and V. Massay : J. Biol. Chem., 240, 2209-2215 (1965).

5) R. C. Bean and W. Z. Hassid : J. Biol. Chem., 218, 425-436 (1956).

6) M. Kobayashi, I. Yokoyama and K. Matsuda : Agric. Biol. Chem., 48, 221-223 (1984).

7) M. Kobayashi, I. Yokoyama and K. Matsuda : Agric. Biol. Chem., 50, 2585-2590 (1986).

8) G. Avigad, D. Amaral, C. Asensio and B. L. Horecker: J. Biol. Chem., 237, 2736-2743 (1962).

9) J. D. Sallivan and M. Ikawa:Biochim. Biophys. Acta, 309, 11-22 (1973).

10) M. Takada, K. Ogawa, S. Saito, T. Murata and T. Usui : Oyo Toshitsu Kagaku (J. Appl. Glycosci.), 44, 
213-221 (1997).

11) H. Murakami, J. Kouno, H. Yoshizu, H. Nakano and S. Kitahata : in Abstract of Papers, the Annual Meeting of the Japan Society of Bioscience, Biotechnology and Agrochemistry, Tokyo, p. 42 (1997).

12) E. A. Peterson and A. R. Torres: Methods Enzymol., 104, 113-133 (1984).

13) H.-Y. Hu and A. M. Gold: Biochemistry, 14, 22242230 (1975)

14) K. Jung and M. Pergande: Methods Enzymatic Anal., 6, 228-238 (1984).

15) C. L. Mehltretter : Adv. Carbohydr. Chem., 8, 231233 (1953).

(Received April 16, 1998; Accepted November 16, 1998)
高濃度のグルコースオキシダーゼによる

ウロン酸の酸化

小林幹彦，西原宏史 ${ }^{1}$ ，小林昭一

農林水産省食品総合研究所 (305-8642 つくば市

観音台 2-1-2)

1 茨城大学農学部 (300-0393 茨城県稲敷郡

阿見町 3998)

3 種類の市販品酵素のグルコースオキシダーゼ (GOD）はグルクロン酸，ガラクツロン酸に作用して 糖酸を生成する作用を有することが認められた。 GOD の最適反応条件は $\mathrm{pH} 8.0,50^{\circ} \mathrm{C}$ であったが, ウロン酸酸化酵素 (UOD) 活性の最適条件は $\mathrm{pH} 3.5$, $40^{\circ} \mathrm{C}$ であった，GOD 活性と UOD 活性を分離するこ とができなかったため, UOD 反応は GODの基質特 異性の一部に帰因するものと推定された。ウロン酸に 対する $K_{\mathrm{m}}$ がグルコースの 6 倍も高いことも，UOD 反応が GOD の副反応であることを示している．しか しながら, UOD が GOD とは別の酵素である可能性 も否定できないため, 両酵素の異同性に関してはさら に検討が必要である。ウロン酸からの反応生成物を HPLC, ペーパークロマトグラフィーで分析した結 果, 糖酸の標準品と一致する挙動を呈する成分の存在 が確認された。 